\title{
Osmanlı Toplumunda Müslüman Kadının Mahremiyeti: Urfa Örneği (1866-1895)
}

\section{Abdullah EKiNCí2, Serkan ȘENEL ${ }^{3}$}

Öz

Bu çalışmada geç dönem Osmanlı Urfa'sında özellikle Müslüman kadının mahrem sınırlar ölçüsündeki yaşantısı incelenmektedir. Urfa kadınının toplumsal hayattaki sınırlarını anlamaya çalışırken şehrin kadınlara bakan yönüyle mekânsal yapısı mercek altına alınmıştır. Böylece kentin imkânlar dâhilinde sunduğu verileri mekân-insan ilișkisi düzleminde kadın perspektifinden açıklamak mümkün olmuştur. Osmanlı mahkeme kayıtları olan şer'iyye sicilleri toplumun her tabakasına mensup insanların dünyasını anlamak için büyük önem taşımaktadır. Urfa şer'iyye sicilleri de zengin muhteviyatıyla yereldeki kadının dünyasını belli ölçüde sunacak önemli ipuçlarını içermektedir. Dolayısıyla çoğunlukla 1866-1895 yıl aralığını kapsayan sicillerin kullanıldığı bu çalışmada özellikle Müslüman Urfa kadınının mahrem yaşamını tanımlayabilmek ve anlamlandırabilmek amaçlanmıştır.

Anahtar Kelimeler: Osmanlı, Urfa, Kadın, Müslüman, Mahremiyet.

\section{The Privacy of Muslim Women in the Ottoman Society: The Case of Urfa (1866-1895)}

\begin{abstract}
In this study, the life of Muslim women, especially in the late Ottoman Urfa, is examined within the limits of secluded limits. While trying to understand the borders of the Urfa woman in social life, the spatial structure of the city from the point of view of women has been scrutinized. Thus, it was possible to explain the data presented by the city within the possibilities from the perspective of women in the space-human
\end{abstract}

\footnotetext{
1 Bu çalışma, "Serkan Şenel, Geç Dönem Osmanlı Urfa'sında Kadın, Kadının Sosyo-Ekonomik Statüsü ve Mahremiyeti (1845-1915), Yüksek Lisans Tezi, Harran Üniversitesi Sosyal Bilimler Enstitüsü, 2018” başlıklı tez çalışmasından yararlanılarak üretilmiştir.

${ }^{2}$ Prof. Dr. Abdullah EKINCi, Harran Üniversitesi Fen Edebiyat Fakültesi Tarih Bölümü, aekinci@harran.edu.tr, ORCID ID: 0000-0002-4767-2002.

3 Arş. Gör. Serkan ŞENEL, Harran Üniversitesi Fen Edebiyat Fakültesi Tarih Bölümü, serkansenel@harran.edu.tr, ORCID ID: 0000-0002-7219-4057.
} 
relationship plane. The Ottoman records, which are Ottoman court records, are of great importance for understanding the world of people belonging to all levels of society. Urfa court registers also contain important clues that will present the world of the local woman to a certain extent with its rich content. Therefore, in this study, in which registers covering mostly 1866-1895 years were used, it was aimed to define and make sense of the private life of the Muslim Urfa woman in particular.

Keywords: Ottoman, Urfa, Woman, Muslim, Privacy.

\section{Extended Abstract}

In this study, the Muslim Urfa woman was handled with the theme of privacy through court registers between 1866 and 1895. The private and nonconfidential relationship indicates the person's daily relationship with those who are halal and non-halal to him or her. In this respect, privacy reveals itself in the space. The house and the street can be regarded as privacy areas by determining the shape of these relationships. Indeed, the street is part of the neighborhood and the house is part of the street. In this context, when we look at the streets and houses of Urfa, it is possible to trace the privacy of women.

Urfa houses are the external reflection of the destructive walls. The limits of private life are manifested in Urfa houses with the physical boundary of the dwelling. In these traditional houses, there are mostly selamlik and haremlik structures. The dimensions of privacy increase when you switch from selamlik to haremlik. The privacy, which started in the neighborhood, gradually passes from macro to micro to the street, from the street to the dead-end street and from there to the house, and it is graded in the rooms of the house. In this regard, we focused on looking at the social life of Urfa through the places used by the Muslim woman in her private life. We tried to evaluate the Muslim Urfa woman among the neighborhood, street, house, court, and bath. Thus, we approached the recent social history of Urfa; there was an opportunity to understand how women are in society and how they are going. It is aimed to examine the image of a Muslim woman in Urfa based on their records, thanks to the clues obtained in them.

This study on Urfa women without registers could not be done. The concepts of privacy, which is seen in female-male relations, have a definition that draws the boundaries of the relations between the two sexes and takes into consideration the factors of religion, community, time, and space while determining these boundaries. Islam has shown the criteria of privacy by drawing a certain legal framework to maintain human relations in society healthily. In this study, we will try to evaluate the concept of privacy in the context of the reflection of Islamic understanding in Urfa society. To what extent was the Muslim woman affected by the definition of privacy in the late Ottoman Urfa? What were the areas that gave Urfa women freedom of movement and what was the feature of these areas? Where was the Urfa woman able to stand in the separation of public and private spaces? After reaching the answer to 
these questions, we will evaluate the privacy of the woman of Urfa through the examples of cases and the kinds of expressions that can be regarded as private in the Urfa district, between 1866 and 1895.

We will try to show that the Muslim woman in Urfa is not trapped only between the four walls of her house, as it is supposed to be. In this context, we will see that women can easily apply to the court in person in line with their right to seek rights, or they can hire a Muslim or non-Muslim male representative. We will also read information about the street practice of women that they can get together on the dead-end streets, filling the water from the neighborhood fountain, going to the bathhouse on certain days determined for them, and organizing entertainment in the form of henna-bridal baths at the entrance of the bath. In addition to registries, fatwa samples and observations of travelers visiting the city were also used. 


\section{Giriş}

Kadın-erkek ilişkilerinde kullanılagelen mahrem ve namahrem kavramları iki cins arasındaki ilişkilerin sınırlarını çizen ve bu hudutları belirlerken din, cemaat, zaman ve mekân faktörlerini gözeten bir tanıma sahiptir. İslam, toplumdaki insan ilişkilerini sağlıklı bir şekilde devam ettirebilmek adına belirli bir hukuki çerçeve çizerek mahremiyetin ölçütlerini göstermiştir. Mahremiyet kavramını bu çalışmada İslami anlayışın Urfa toplumundaki yansıması bağlamında değerlendirmeye çalışacağız. En başta mahremiyetin hemen hemen her toplumda farklı formlarda tezahür ederek varlığını sürdürdüğünü ifade etmek gerekir. Örneğin, Avrupa'da dokunmak ve temas etmek mahremiyetin sınırı olarak kabul edilirken Osmanlı'da görme veya bakma üzerinden bir mahremiyet perspektifi çizilmiştir (Bilgin, 2018: 304). İslâm dini, karşı cinsler arasındaki ilişkilerde insanın tabiat ve eğilimlerini göz önünde bulundurarak hem fıtratı ve tabii olanı korumak hem de aşırılıkları önlemek amacıyla tarafları muhtemel sapmalardan koruyucu bazı sınırlamalar getirmiştir. Bu anlamda mahrem kelimesi sözlükte "helâl olmayan, yasaklanan şey" mânasındadır ve fıkıh terimi olarak kendileriyle evlenilmesi dinen yasaklanmış bulunan belli derecelerdeki akrabayı ifade eder (DiA, 2003: 27/ 388-389). Bu kavramı doğrudan Urfa kadını özelinde değerlendirmeye geçmeden evvel Özer Ergenç'in sözcüğün kapsadığı sınırı esneterek yaptığı tanımlamaya göz atmak mahremiyetin sınırlarını düşünürken bize geniş bir yelpazede mahrem olanı düşünme imkânı sağlayacaktır. Ergenç, Osmanlı toplumunun çeşitli taifelerden oluştuğunu belirtmiştir. Müslüman veya gayrimüslim oluşlarına veya insanların bir meslek grubuna üyeliğine göre toplum içerisinde farklı farklı mensubiyetlerinin olduğunu ifade etmiştir. Bu yapısal durumda taifenin üyeleri hem etkilenen hem de etkileyen özelliğini taşımaktadır. Bireylerin toplum içinde birden çok aidiyeti bulunduğu için her bir aidiyetlerinden kaynaklı olarak da ayrı ayrı mahrem tanımları oluşmuştur (Ergenç, 2013: 14). Geç dönem Osmanlı Urfa'sında kadın bu mahremiyet tanımından ne ölçüde etkilenmiştir? Urfa kadınına hareket özgürlüğü tanıyan alanlar nerelerdi ve bu alanların özelliği neydi? Kamusal ve özel alan ayrımında Urfa kadını nerelere ayak basabiliyordu? Bu soruların cevabına ulaştıktan sonra Urfa kadınının mahremiyetini 1866-1895 yılları arasındaki Urfa şer'iyye sicillerinde geçen dava örnekleri ve mahrem sayılabilecek ifade çeşitleri üzerinden değerlendireceğiz.

Bu çalışmada, Müslüman Urfa kadınının zannedildiği gibi sadece evinin dört duvarı arasında sıkışıp kalmadığını göstermeye çalışacağız. Bu bağlamda kadınların yeri geldiğinde hak arama çabası doğrultusunda bizzat rahatlıkla mahkemeye müracaat edebildiklerini ya da kendilerine Müslim veya gayrimüslim erkek vekil tutabildiklerini göreceğiz. Kadınların sokak pratiğine dair çıkmaz sokaklarda bir araya gelebildiklerini, mahalledeki çeşmeden su doldurabildiklerini, ayrıca kendileri için belirlenen bazı günlerde hamama gidebildiklerini ve burada kına-gelin hamamı türünden eğlenceler düzenlediklerini ve hamamın girişinde sohbet ortamı kurduklarına dair bilgiler okuyacağız. Hatta bir seyyahın gözleminden aktarılan notlarda bazı kadınların 
yüzmeye dair bir pratiklerinin olduğuna dair gözlemleri de paylaşacağız. Osmanlı taşrasında yaşayan kadınları genellikle şer’iyye sicilleri üzerinden, fetva örneklerinden ve şehri ziyarete gelen seyyahlar üzerinden takip edebildiğimiz için taşra kadını anlatımlarında kaynaklara erişim ve bu kaynakların çeşitliliği oldukça sınırlı sayıdadır. Ancak, ilgili kaynakların vermiş oldukları ipuçları ölçüsünde Müslüman Urfa kadınının mahrem yaşamı ve sınırı hakkında mekân ve sözcüklerin üzerinden birtakım çözümlemeler yapabilmek mümkündür.

\section{Urfa'da Müslüman Kadının Mahalle ve Sokaktaki Mahremiyeti}

Mahremiyet tanımının mekân ölçeğinde felsefi arka planına diğer bir açıdan eğilmeye çalıştığımızda ise Müslüman hukukçular mekân meselesini kadının ve erkeğin karşılıklı etkileşim meselesi olarak ele almışlardır. Mekânın cinsiyetlendirilmesi erkek ve kadın arasında bazı sosyal sınırların korunması ve kadın-erkek etkileşiminin titizlikle düzenlenmesi gerektiği fikrinden ileri gelmektedir (Ergenç, 2013: 14). Tucker'in iddia ettiğine göre çarşı, pazar ve idari mekânların düzenlemesinde kadın-erkek ayrımı Müslüman toplumlarda net bir şekilde çizilmemiştir. Yazarın söz konusu yorumu genelleştirilebilir mi bunu sorgulamak gerekebilir. Ilerleyen sayfalarda bahsedeceğimiz muhadderat kavramının çizmiş olduğu sınırda evden çıkmayan bir kadın profili var ve hukuku temsil eden bir memurun muhaddere olan kadının evine gidip ifade alması söz konusu. Peirce'ye göre bu şeriatın getirmiş olduğu bir yaklaşımdan kaynaklıdır. Bu tür örneklerin diğer yansımalarını Urfa evlerinin yapısından bahsederken veya kadınların hem Urfa'da hem de Osmanlı İmparatorluğu'nun diğer illerinde vekil kullanma oranlarından da çıkarabilmek mümkündür. Buradan hareketle denilebilir ki Müslüman toplumlarda kadın-erkek mekân kullanım ikiliğinin olmadığı şeklinde vargıya ulaşmak yanıltıcı olabilir. Müslüman toplumlarda mekânın cinsiyet temelinde ayrılmasına değinen Tucker, bu ayrımın ibadetlerin yerine getirilirken bir düzen tesis edilmesinden meydana geldiğini ifade etmiștir. Kadınlar ve erkekler dini yükümlülüklerini evde, camide veya hacda nasıl yerine getirmelidir? (Tucker, 2015: 254) sorunsalından hareketle Müslüman toplumlarda cinsiyet temelinde cinsler arasındaki teması ayırmaya yönelik mekânsal mahrem düzenlemelerin ortaya çıktığı kabul edilir.

Mahalleli birbirini yakından tanıdığı için herhangi bir olayda, bir kişinin durumu hakkında komşularının ve mahalle imamının tanıklığının büyük önemi vardır. Bu yüzden çoğu kez, mahkemede kanıtlar ve görgü tanıklarının sözleri değerlendirilirken, bir de sanığın mahallesinde nasıl tanındığı araştırılmaktadır (Ergenç, 1984: 74). Urfa'ya ait birçok şer'iyye sicilinde de görüldüğü üzere ifade etmek gerekirse insanlar aidiyetlerini mekân üzerinden tanımlıyorlardı. Örneğin, Urfa sicillerinde öncelikle "Medine-i Urfa mahallatından falanca mahalleden" şeklinde başlayan ifade şekli mahkemenin davaya konu olan tarafların derdini dinledikten sonra kayda geçerken girizgâh olarak kullandığı bir söz kalıbıdır. Daha sonra belgedeki şahıslar sâkini oldukları mahallerinde bulunan evinin yanındaki 
ve kendisine mahrem olan komşuları üzerinden sicillerde tanımlanmaktadır. Bu şahıslar, şahitler huzurunda kendisinin kim olduğunun ta'rifini mahkemeye sunmaktadır. Bu sebeple Osmanlı toplumunda kişiler arası mahrem ilișkileri tanımlarken mahalle önemli bir öğedir. Taifeler, mahalleler, evler ve evlerin odaları şeklinde hiyerarşik bir şekilde dışarıdan içeri doğru artan bir mahremiyet derecesi vardır. Hatta öyle ki Osmanlı Urfa'sında mahallelerin kapısının olduğu dahi saptanmıştır. (Ekinci, 2018: 20).

Mahalleler şehri oluşturan önemli birimler olması sebebiyle kentlerin dikkate değer bir öğesidir. Nitekim Osmanlı şehirleri oluşturulurken mahalle belirli bir dini ve toplumsal anlayış çerçevesinde oluşturulmaya çalışılmıştır. Mahalle kadar önemli olan bir diğer yapı taşı da hiç şüphesiz sokaklardır. Osmanlı sokakları sosyal değerler yönü ile içerisinde dayanışma, sorumluluk ve mahremiyeti barındıran özellikleri ile dikkat çekmektedir. Bu yönüyle mahalle şemsiyesi altında sokak, mahallenin bir alt birimi olarak yapılanmıştır. Osmanlı şer'iyye sicillerinde sokak kavramı genellikle "zokak", "tarîk-i “amm” ve tarîk-i hass" şeklinde belirtilir. Bu kavramlardan tarîk-i "amm, anayol ya da herkesin gelip geçebildiği, kullanabildiği yol gibi manalar taşırken tarîk-i hass çıkmaz sokak anlamına gelmekteydi ve içinde toplumsal ve dini anlayışa atıfta bulunan bir manayı taşımaktaydı (Ekinci, 2018: 11). Öyle ki Osmanlı mahallelerinde sokakların çıkmaz sokak olması bir mahremiyet nişanesiydi. Haremlik ve selamlıktan oluşan hayatlı evlerin içerdiği mahremiyet algısı adeta sokağa da taşmıştı. Tıpkı evlerin koridoru gibi olan bu sokaklar, Cem Behar'ın deyimiyle bir özel sokak statüsündeydi (Behar, 2004: 84). Çıkmaz sokağa bağlanan evler "tarîk-i hass ile mahdud” olarak anılmaktaydı yani Behar'ın yorumuyla kamuya açık değil özeldi. İster Müslüman olsun isterse gayrimüslim, insanlar anlaşma ve anlaşmazlıklarını öncelikle mahalledeki din görevlisi ve ileri gelenler, loncalar ya da müftülük gibi müesseseler aracılığı ile halletmeye (sulh) çalışmaktadır (Uğur, 2015: 300). Bu sokaklarda komşular birbirlerini bilirler ve sokakta yeni bir ev yapıldığında bu evin kapısının nereden açılacağı hususunda kadı bizzat gidip soruşturma yapar ve uygun görmediği takdirde kapıyı açtırmazdı (Doğan, 2002: 18). Bu yaklaşım komşu hakkını ve sokağın yapısını korumaya çalışmak olarak değerlendirilebilir. Buna izn-i şüreka denmekteydi (Behar, 2004: 86). Yan yana komşulukların oluşturduğu dolambaçlı ve kavisli yolların üzerinde kurulan bu komşuluk ilişkilerini Ergenç, üzüm salkımı metaforu ile bize aktarırken bitişik komşuluk anlamında kullandığı car-ı mülasık veya car-ı hem civar adı altında da bu yan yana komşulukları tanımlamaktadır (Ergenç, 2013: 17).

Mahrem ve namahrem ilișkisi kişinin kendisine helal olan ve olmayanlarla gündelik ilişkisini belirtmektedir. Bu yönüyle mahremiyet kendisini mekânda oldukça belli etmektedir. Ev ve sokak bu ilişkilerin şeklini belirlemesi itibariyle mahremiyet alanları olarak kabul edilebilir. Nitekim sokak mahallenin, ev ise sokağın bir parçasıdır. Ev, bir sokakta oturanların bir parçasını temsil eder (Ekinci, 2018: 9). Bu bağlamda Urfa sokaklarına ve evlerine baktığımızda kadınların mahrem yaşamına dair iz sürmek mümkündür. Zira insanların yaşam alanı ve 
günlük vakitlerinin önemli bir kısmını içinde geçirdikleri bu mahallin toplumsal bir iz barındırmaması mümkün değildir. En başta ifade etmek gerekir ki Osmanlı siyasî yapı ve kültürü, içinde bulunduğu toplumsal âdet ve geleneklere aşırı duyarlı idi (Uğur, 2015: 294). Osmanlı Devleti mahallelerin önemli bir parçası olan sokakları tasarlarken sosyolojik kaygılar gütmüş ve sokakların fiziksel görünümlerini bu toplumsal ve dini inanışlar çerçevesinde inşa etmeye çalışmıştır. Mahallelerde bulunan evlerin yapısı ve kullanım biçimi Osmanlı şehirleri açısından yine üzerinde durulması gereken bir husustur. İçe dönük olarak, avlulu ve genelde iki kat olarak inşa edilen evler mahremiyetin, kadın erkek ilişkilerinin, komşuluk bağlarının ve toplumsal sorumluluğun önemli yansımalarını içinde barındıran yapılardır. Hatta evdeki bu izdüşümlerin bir kısmı sokağa da taşar ve çıkmaz sokaklardan oluşan mahalle düzeni ile karşı karşıya kalınır (Uğur, 2015: 310).

Geleneksel Urfa mahallelerine baktığımızda da mahremiyetin yansımasını hem sokak yapılarında hem de evlerde görebilmek mümkündür. Urfa şer’iyye sicillerinde geçen ve çıkmaz sokak anlamına gelen tetimme kavramı halk ağzında tetirbe olarak söylenmektedir. Tetirbeler olarak ifade edilen sokağa bağlanan evler "tarîk-i hass ile mahdud" olarak kamuya açık değil özeldi (Ekinci, 2018: 12). Bu sokaklar genellikle kavisli, dolambaçlı ya da ivivaçlı (Bayartan, 2005: 89) idi. Tetirbelerde çocukların oyun oynadığını kadınların sohbetler ettiğini öğrenmekteyiz. M. Fuat Kürkçüoğlu anılarını anlattığı romanında bu çıkmaz sokaklarda gülle peste, koza kırık ve çelik çıbı oyunlarını oynadıklarını anlatmaktadır (Kürkçüoğlu, 2018: 147). Dolayısıyla bu sokakların bir yönü de Urfa'nın sözlü tarihine ışık tutmaktadır.

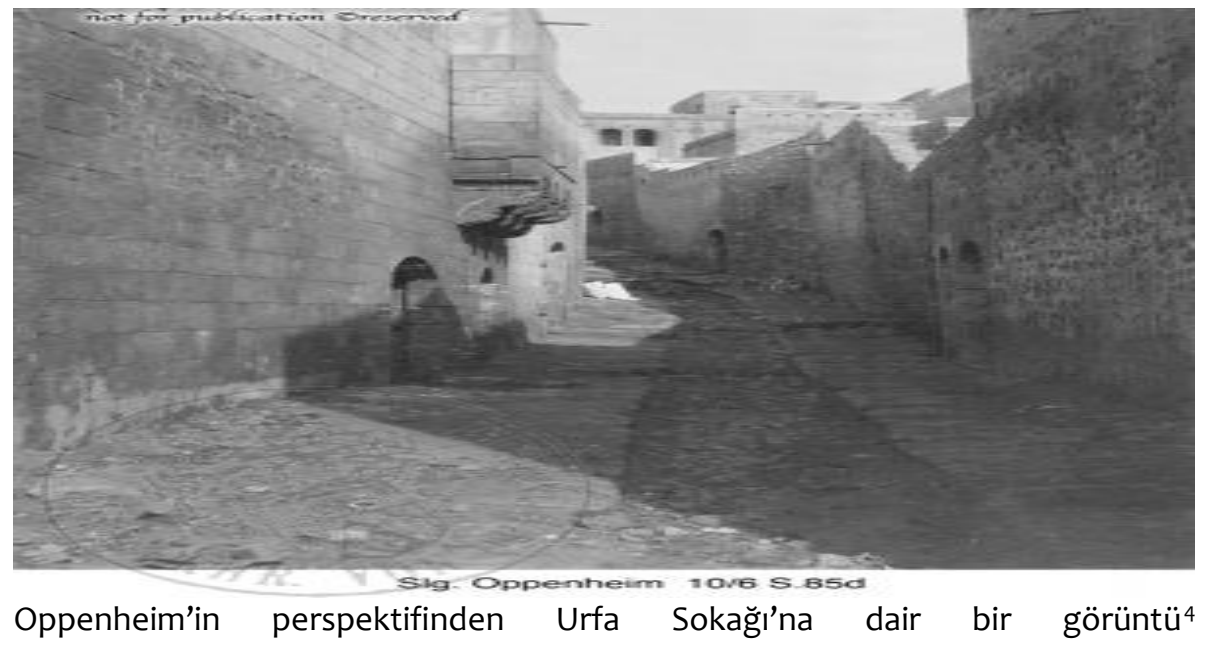

\footnotetext{
4 “Fotosammlung Max von Oppenheim - Seriennummer: 9005, 10/6, 85d", erişim: 09.10.2018. https://arachne.unikoeln.de/drupal/?q=node/2
} 


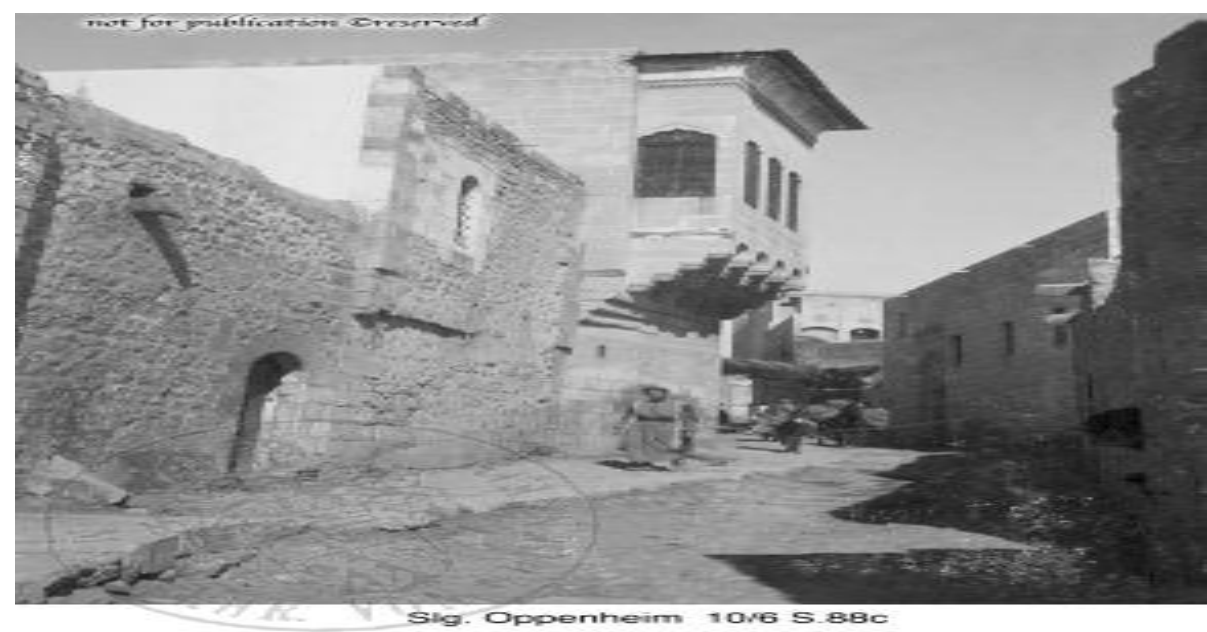

Oppenheim gündelik hayatın akışı içinde bir Urfa Sokağ ${ }^{5}$

Gerek iklimsel koşulları minimize etmek amacıyla gerekse mahremiyeti gözetmek amacıyla Urfa evlerinin duvarları yükseltilmiştir (Ekinci, 2018: 14). Yerasimos'a göre “islâm kenti, bir uçtan öbürüne, bir mahalleden diğerine kişilerin diledikleri gibi geçebilecekleri bir alan değildir; kapı, çarşı, ulu camii gibi kamusal niteliği en belirgin yerlerin en özel mekân olan eve büyük sokak, küçük sokak ve çıkmaz sokak aracılığıyla, yani gittikçe kamudan özele geçmeyi sağlayan bir ilerlemeyle varılabilir. Çıkmaz sokak mahremiyetin ve korunmanın bütün avantajlarına sahiptir" (Üner, 2015: 24). Osmanlı İmparatorluğu'nda neredeyse tüm kadınlar sokakta edebe aykırı hareket etmemişler ve sokaklarda benzer giysilerle görünmüşlerdir (Ekinci, 2018: 17). Toplumsal talep ve anlayış doğrultusunda oluşturulan yapılarda ona göre de davranılması beklenmektedir. Aslında bu da mahremiyetin bir tür yansıması olarak karşımıza çıkmaktadır. Urfa evlerinde dam geleneği örneğini veren Aynur Can bunun hem talep meselesi hem de mahremiyet ile olan geleneksel bağını örnek vermektedir. İnsanlar mekânı inşa ederken talepleri doğrultusunda mekân inşasına katılımları söz konusudur. Bu bakımdan adalet ve mahremiyet kavramları da mekân ölçeğinde yerine oturmaktadır. ${ }^{6}$

\section{Urfa'da Müslüman Kadının ve Ev Halkının Hanedeki Mahremiyeti}

Bir sınır çeşidi olarak duvarlar Orta Çağ ve Modern dönem öncesi İslâm hukukunun meşru (helâl) ve yasak (harâm) olanı ayırmada kullandığı birer vasıtadır. Diğer bir ifadeyle seküleri kutsaldan ayırmada, kadınları erkeklerden

\footnotetext{
5 “Oppenheim, 10/6, 88c", https://arachne.uni-koeln.de/drupal/?q=node/2

${ }^{6}$ Bisav TV: “Aynur Can, “Güzel Şehrin Esaslarını Anlamak”, Bir Şehir Kurmak ve Yeni Bir Gündem Inşa Etmek”, erişim: 10.10.2018. https://www.youtube.com/watch?v=4VTetDI2Guw
} 
ayırmada, gayrimüslimleri Müslümanlardan ayırmada diğer dünyadan ayrılan özel dünyada duvar mefhumu önemli bir araçtır. Bunların yanı sıra, pek çok toplum adet, ikamet, korunma ve kontrol gibi çeşitli nedenlerle duvarlara hususi bir itimat göstermiştir (O' Meara, 2014: 67). Urfa evleri mahremin duvarlarının yıkılmaz hale gelişinin dışa yansımasıdır. Özel hayatın sınırları, konutun fiziksel sınırı ile Urfa evlerinde kendini göstermektedir. Bu geleneksel evlerde çoğunlukla selamlık ve haremlik yapıları bulunmaktadır. Selamlıktan haremliğe geçildiğinde mahremiyetin boyutları artmaktadır. Mahallede başlayan mahrem, makrodan mikroya aşama aşama sokağa, sokaktan çıkmaz sokağa ve oradan da eve geçmektedir ve evin odalarında da kendi içerisinde derecelenmektedir. Özer Ergenç, Aynur Can ve Yunus Uğur gibi şehir tarihçileri bu hiyerarşiyi iç-dış ilişkisi olarak yorumlamaktadır. Selamlık genellikle eve gelen misafirlerin ağırlandığı bölümdür. Özellikle ramazan aylarında selamlık bölümü oldukça aktiftir. Genellikle bu bölümde misafire ait bir de oda bulunur (Kalender, 2013: 399). Urfa evlerine baktığımızda bir sokak üzerinde bitişik nizamda sıralı olması ama bu bitişiklik içerisinde de mahremiyet çabasının güdüldüğünü görmekteyiz. Nitekim mahremiyetin bekçisi komşular ve konutun fiziksel sınırlarıdır. Cumbalı evlerin göze çarptığı yapılarda hem mahallelinin birbirini tanıdığı hem de bu cumbalar üzerinden mahalleyi gözlemlediği, gözetim altında tuttuğunu da ifade edebiliriz (Kalender, 2013: 399). Urfa evlerinde kadınların kendi alanlarında kurdukları ve hayat denilen bir yaşam alanları vardır. Bu hayatlı evlerin mimarisi adeta kadının rahatça hareket edebilmesi için tasarlanmış gibidir. Kadınların rahatça hareket ettikleri bu alana M. Akif Aydın, makarr-ı nisvan tabirinin kullanıldığını belirtmiştir (Aydın, 2013: 24). Bu tabir Mecelle'de kadının hanesi içinde mutfak, kuyunun başı ve evin avlusu gibi rahatlıkla hareket edebileceği alanları ifade etmek için kullanılmıştır. (Cevdet Paşa, Mecelle-i Ahkâm-ı Adliye, md. 1202, 496.) Bu kavramın bir diğer ifadesi de komşulukla alakalı yönünün olmasıdır. Şöyle ki bir ev inşa edilirken ya da eve yeni bir pencere açılacağı zaman komşunuzun ve çocuklarının rahatça hareket edebileceği bir yöne bu pencereyi açamazsınız. Pencerelerin avluya doğru baktığı Urfa evlerinde de bunun yansımasını net bir şekilde görmekteyiz. Aslında komşuların avlu ve pencerelerini gören evlerin, halk arasında talep görmediği de anlaşılmaktadır. Meselâ, Hüseyin kızı Ayşe ile Mustafa kızı Rukiye, vekilleri Mustafa oğlu Ahmed aracılığıyla Sultân Bey Mahallesi'nden Osman oğlu Abdülkadir ile Ahmed oğlu Marangoz Mahmud'dan içini görmeden 4250 kuruşa bir ev satın alarak parasını ödemişlerdir. Ancak evin içini gördükten sonra bir pencerenin komşu evi görmesi üzerine evi satın almaktan vazgeçerek paralarını geri almışlardır (Taş, 2016: 6). Urfa evlerinde içdış mahremiyet yansımasını birebir görebileceğimiz yapılar mevcuttur. "iç̧" derin mahremiyetin alanıysa, "dış", toplumsal etkinliklerle aile yaşamının arakesit bölgesidir ve daha bir sığ mahremiyete sahiptir (Tanyeli-Gerçek, 2012: 20). Hatta öyle ki içteki mahremiyet kısım kısım daha da artmaktadır. Şahıslara ait özel odaların olduğu ve haremlik kısmında evlerin ikinci katlarının olduğuna şahitlik etmekteyiz. Evlerin içerisinde mutfaklarının olduğu sandık odalarının bulunduğu ve banyoların yer aldığı yapılar bulunmaktadır. Dahası bazı evlerde odadan 
banyoya özel geçitlerin olduğunu Urfa evlerinin çizilen planları sayesinde görmekteyiz. Banyo çoğunlukla evlerin haremlik kısmında yerini almıştır. Kadınların ev içi alanlarda en çok vakit geçirdikleri bölümler olarak tanımlanan makarr-ı nisvânın komşu pencereleri tarafından görülmemesi elzemdi. Bu sebeple yer yer tartışmalar olmuştur. Üstelik bu kaygı sadece Müslüman ahalide değil gayrimüslimlerde de hissedilmiştir. Mimar Agob'un, Vanis'in oğlu Koko ile komşusu Bido arasındaki tartışma konusu pencere yerinin kontrolü için gönderilişi de bu minvalde gerçekleşmişti (Asoğlu, 2019: 188). Ayrıca mecelle'de yer alan bir madde de bu durum açık bir şekilde belirtilmiştir. Bu maddede belirtildiğine göre makarr-ı nisvan sayılan (mutfak, kuyunun başı ve evin avlusu) gibi alanların komşu tarafından görülmesi zarar-ı fâhiş olarak adlandırılır. ilgili alanlar car-ı mülasık sayılan komşu tarafından görülüyorsa engelleyecek şekilde duvar çekilmelidir (Ahmet Cevdet Paşa, 1300: Mecelle-i Ahkâm-ı Adliye, md. 1202, 496). Bu durum mahremiyetin içerideki katmanlarda da devam ettiğinin en güzel örneklerinden birisidir. Bu bağlamda mahremiyeti yalnızca dışa yönelik değil içerdeki aile yaşamında da aramak gerekir. Ebeveynlerin çocuklarıyla veya çocukların ebeveynleriyle olan gündelik yaşamlarında da bu çizgi varlığını farklı formlarda korumuştur.

Elbette her Urfa evi anlatıldığı kadar geniş değildi, çok dar, bireyi sıkan ve onu tehdit eden, huzursuz eden alan kısıtılığının olduğu evler de vardı. Nitekim bazı kadınların mahkemeye başvurduklarında kocasının diğer eşiyle aynı hanede kalmak istemediklerine ya da kayınvalide ve görümceleriyle aynı evde yaşamak istemediklerine dair bilgi sahibi olduğumuz dava örnekleri mevcut (BOA, MŞH. UŞS: 210/199-1. BOA, MŞH. UŞS: 220/988-253). Dolayısıyla Tanyeli'nin ifadesi ile kadına hareket özgürlüğü katan bu mahrem alanlar aslında lüksle de ilişkilidir. Diğer bir ifadeyle mahremiyet lükstür, yani bir imkân meselesidir. Koşulların elverişli olmadığı durumlarda mahremiyeti tam manasıyla hissetmek de mümkün olmayabilir. Mekânın kısıtılığı mahremiyeti tamamen ortadan kaldırmayabilir fakat yeterince bir mahremiyetin oluşmasına da imkân vermeyebilir. Bu anlamda bir orantı vardır ama eğer mekân sınırlı ise mahremiyet yoktur sonucuna da varamayız (Yaşar, 2013: 89). Pekâlâ, bir odada yaşayan ailelerde de mahremiyet disiplini vardı ancak bir odalı evde mahremiyeti yaşamak ile yirmi yedi odalı bir konakta yaşamak ayrıdır (Tanyeli, 2013: 112). Bu bakımdan son döneme ait geleneksel çok odalı Urfa evlerinden birisinin örneğini paylaşmak konunun anlaşılması bakımından yerinde olacaktır kanaatindeyiz. 


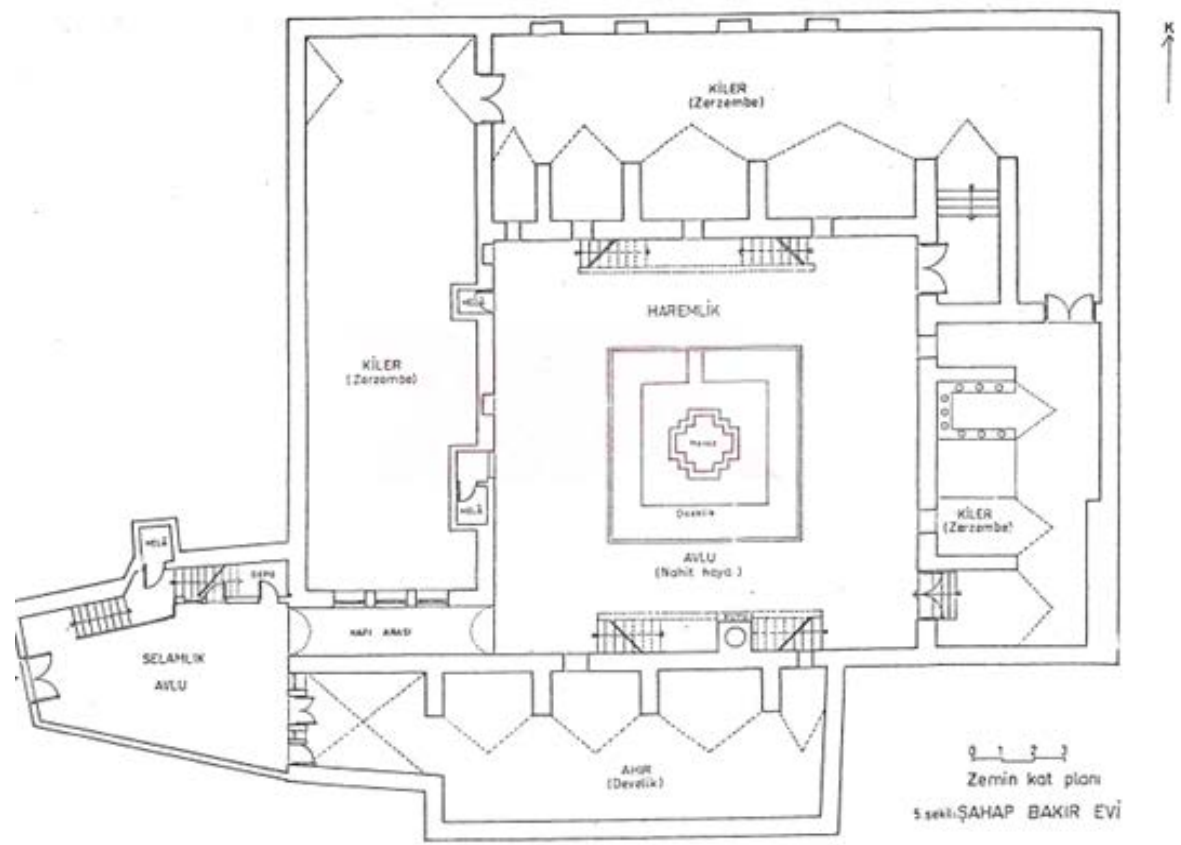

Şahap Bakır Evi'nin Zemin Kat Planı (Akkoyunlu,1988: 10)

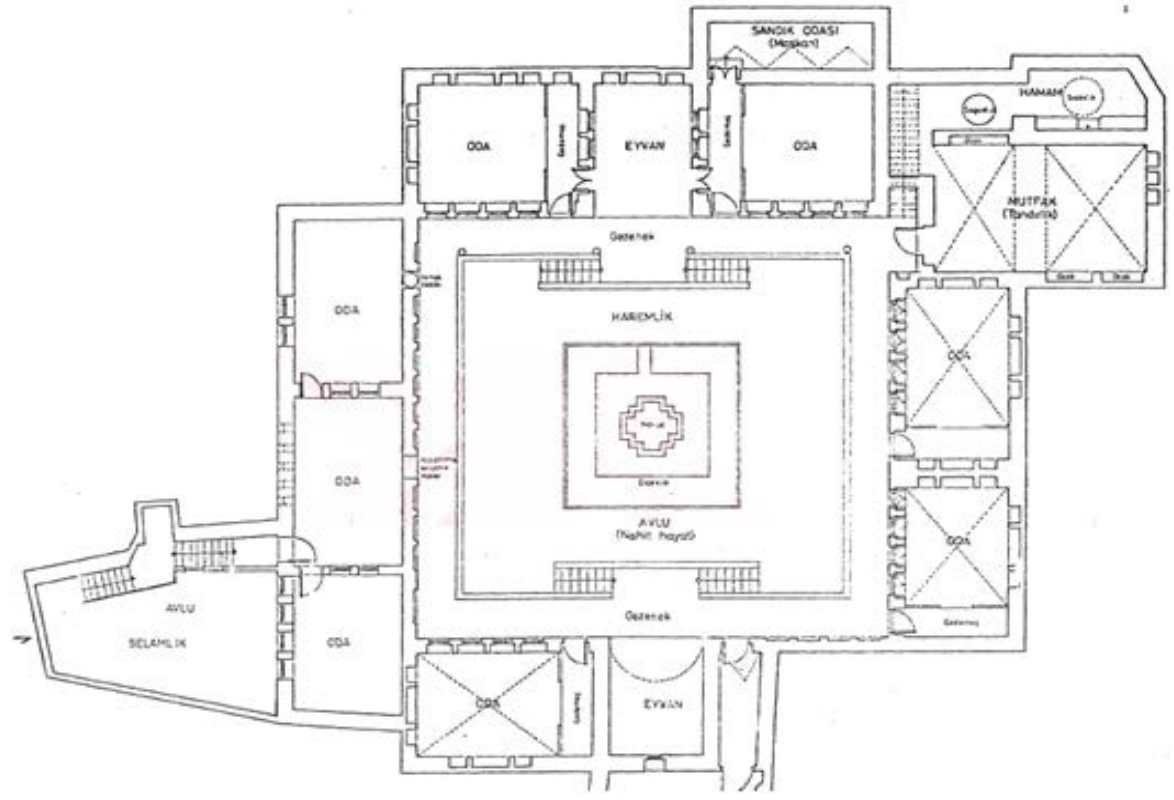

Şahap Bakır Evi 1. Kat Planı (Akkoyunlu,1988: 11) 
Bu tür Urfa evlerinin sayısını çoğaltmak mümkündür. Hacıbanlar evi, Melekler evi, Hacı İmam Demirkol evi, Ömer Göncü evi ve Abdülkadir Hakkarî evi bu evlerden sadece birkaçıdır (Akkyounlu, 1988). Mahremiyet, korunaklı ve rahat bir yaşam için inşa edildiğini düşündüğümüz bu çok odalı evlere karşı Oryantalist bakış açısı olarak değerlendirilebilecek yaklaşımlarda çok eşlilik için bu tür yapıların kullanıldığı ve bu yüzden oda sayılarının çok olduğu gibi yorumlar da yapılmıştır. (Orhun, 2010: 3400-355). Osmanlı İmparatorluğu'nun diğer şehirlerinde olduğu gibi Urfa'da da çok eşlilik oranının düşük olduğunu $(\% 14,2)$ ifade etmek gerekir (Şenel, 2018: 39). Ayrıca bu tür yapıların inşa edilmesi kamusal alanlarda erkeklere oranla nispeten daha az görebildiğimiz Urfa kadınına kendi evinin dünyasında özgürlük sağlamıştır. Bu evleri inşa eden insanların yaşam tarzları ve maddi gelirleri de bu imkânların oluşmasında etkili olmuştur. Evin kadını sadece Urfa'da değil diğer Anadolu kentlerinin hayatlı evlerinde de çamaşır yıkamak, yemek yapmak, yün eğirmek, komşularıyla sohbet edebilmek ve çocuklarıyla rahatça ilgilenebilmek adına avlulu evleri kullanmıştır (Dengiz, 2001).

\section{Müslüman Urfa Kadının Sosyal Hayatı ve Mahremiyeti}

Urfa kadınının mahrem yaşantısını oluşturan ve aynı zamanda sosyal hayat yönüne ışık tutan bir öğe de hiç şüphesiz birçok Osmanlı kentinde olduğu gibi kadınların hamama gitme pratiğidir. Urfa'da Osmanlı döneminde aktif olarak erkekler ve kadınlar tarafından kullanılan hamamların olduğunun bilgisine sahibiz (Gülbiçin, 2006). Örneğin şehirdeki hamamlardan vezir hamamının doğu kısmı kadınlara, kuzey kısmı erkeklere aittir. ${ }^{7}$ Hamamlar Urfa'da gece ve sabahtan öğlene kadar erkeklere, öğleden sonra ise bayanlara hizmet vermekteydi. Hamamlarda görevli erkek yıkayıcılara "dellek", kadın yıkayıcılara ise "kêyme" adı veriliyordu. Kadın görevlilerden "natır" ise hamama gelen hali vakti iyi ailelerin hamam gereçleri ve eşyalarını taşımakla görevliydi (Kürkçüoğlu, 2014: 40). Kadınların hamama gittiğine dair bilgileri dönemin kadı sicilleri ve şehri ziyarete gelen seyyahların gözlemleri sayesinde öğrenebiliyoruz. Hamamcılığın kadınlar için bir meslek olabileceğine dair izlenim de belgelerden çıkarımlarımız arasında yer alıyor. ${ }^{8}$ Diğer yandan kadınların terekelerindeki gündelik eşyalarına baktığımızda hamam tası, hamam leğeni, hamam urbası ve hamam kilimi gibi eşya isimlerinin çokça geçmesi Urfalı kentli kadınların bu yönde bir pratiğinin olduğunu düşündürmektedir (BOA, MŞH. UŞS: 208/58-269, 208/671-91, 208/67380, BOA, MŞH. UŞS: 210/16-205, 210/27-209, 210/561-178. BOA, MŞH. UŞS: 220/1119335). Bir dava örneğinde Ayşe Ebe'nin yasak ilişkiden meydana gelen bir çocuk düşürme vakası geçmektedir ${ }^{9}$ Bu belgede kadının mahrem mevzusu mahkemede

\footnotetext{
7 Abuzer Akbıyık, “Urfa Hamamları: Vezir Hamamı”, http://www.abuzerakbiyik.com.tr/page_detail.php?page_id=24

${ }^{8}$ HamamcI Rahime ibaresi için bkz. BOA, MŞH. UŞS: 220/669-34.

9 Meşarıkiyye Mahallesi sâkinlerinden ebe Ayişe bt. ilbeyi Muhzır Çilo'ya ve meclis çavuşu Hafız Mustafaya şöyle takrîr itmiş ki iş bu yetmiş iki senesi şehr-i cemâziye'l-âhirin gurrasından yevmi ehad sa'at üç sularında katilin
} 
kayıt altına alınmıştır. Bu tür mevzular mahkeme belgesine yansıdığı sürece öğrenebiliyoruz. Bunun dışında pek fazla öğrenme şansımız olmuyor. Belli ki Ebe Ayşe'nin baktığı kadın yasak bir ilişkiden hamile kalmıştır. Ebe bu bebeğin kimden olduğunu sorduğuna göre kadın evli değildir. Belki de hamamda yasak ilişkisi olduğu adamın karısıyla tartışma yaşadı. Ebe'nin durumu mahkemeye bildirmesi hem kendisini güvence altına almak için hem de bu tür bir yanlışı onaylamadığını göstermek için olabilir. Mahkeme burada ayrıntılarıyla kadına nasıl bir tedavi uygulandığını ve hayz döneminde olup olmadığını öğrenerek bize sunabiliyor. Kişisel yaşama mahsus ayrıntılar, toplumun vakıf olduğu konular arasında bulunabilmektedir. Ancak ilişkinin öznesi olanlar tarafından bilinebilecek bu özel konular, kamusal alanda karşımıza çıkabilmektedir. Insanların birbiri hakkında sahip olduğu bilgiler, bazı hallerde hukuk kuralları gereği insanlar, başkalarıla paylaşamayacakları mahremiyetlerini aşikâr etmek zorunda kalabiliyordu (Yılmaz, 1999/2000: 98). Mahremiyetin mahkemedeki sınırlarını da belirtmesi bakımından bu dava önemli bir yere sahiptir. Kadınların Urfa'da hamama gittiklerini ve birbirleriyle hamamda karşılaştıklarını sicillerdeki belge örneklerinden net bir biçimde görebiliyoruz. Vesile Hanım, Mahmud ile Zemzem'in sütkardeşliği meselesini ben hanemden bir yere çıkmam geçen gün bu keyfiyeti hamamda duydum diyerek aslında kadınların hamamda birbirleri ile sohbet ettiklerini bize haber vermektedir (Benzer, 2015: 242). Nitekim erkeklerin kahvehanede ettikleri sohbet veya dedikoduları kadınlar da hamamda gerçekleştiriyordu. Dolayısıyla kadınların toplumun nabzını tuttuğu ve bir sosyalleşme veya haber alma-yayma merkezi olarak çıkmaz sokaklarda yaptıkları sohbetleri hamamlarda da sürdürdüklerini ifade etmek gerekir. Hamama giden bir kadın kendi evinin mahrem sınırlarının dışına çıkarak sokağa-mahalleye adım atması aynı zamanda kadının özelden kamusal mekâna geçişinin de göstergesidir.

Urfalı kentli kadınların sadece hamama gitme değil aynı zamanda yüzmeye dair de bir pratiklerinin olduğunu tahmin etmekteyiz. Nitekim Urfa'yı ziyarete gelen Buckingham'ın seyahatnamesinde “ibrahim gölünde erkekler ve oğlan çocukları yüzüyordu, bazıları da epey iyi yüzücü, daha küçük olan Zılgah gölünde ise şaşırtıcı bir şekilde bir grup kadın yıkanıyor" diye bahsedilmektedir (Buckingham, 1827: 64). Şehirdeki hamamların şafak vaktinden ikindiye kadar erkeklere, gün batımına kadar ise kadınlara açık olduğunu öğreniyoruz (Buckingham, 1827: 83). Kadınların Çarşamba günü hamama gittiklerini ve hamamın girişindeki sundurmada yastık ve yatakları hazırlayarak bir araya geldiğini ve sohbet ettiklerini de yine seyyahın gözlemleri sayesinde öğrenebiliyoruz (Buckingham, 1827: 84). Seyyah ayrıca bahçelerde gördüğü

hemşiresi bana şöyle takrîr eyledi ki bana hayız vaki' oldu. Nazar eyle didikde ben dahi nazar itdim üç ılık sulu beyan sual itdim ki hâmile bulundığından haize görünmeğe sebep nedir cevap itdi ki orasını sual lâzım değil ma'lûmun hamli bir 'ilaç ile bırak didikde ben cevap itdim ki vebâle girmem hamli bırakmaya talebin neden deyu sual itdim nicedir kesb eyledik didikde hamamda 'iyallerle sebt güni münâza'a itdim bu hayzi gördüm ve bu hamlin bırakılmasına lâkin kimin 'iyalidir didim ise de beyan itmedi ve yirmi altı gün sonra Erbe'a gicesi sa'at dokuz sularında mezkûrun hemşiresi 'indiye gelüb takrîr eylediği hemşirem vaz' idecektir tizce eriş didikde ben dahi vardım bir çeyrek bir el kadar talak misüllü bir şey zahir oldu. Baktım ki üç lık bir kız batnında kokup telef olmuş, sararak çirkap kuyusuna atılmışdır (BOA, MŞH. UŞS: 205/159-68). 
hayattan da kadınlar hakkında bir kesit sunar. Ağaçların altında dinlenen hanımların olduğunu ve onlara hizmet eden hizmetçilerin olduğunu belirtir. Kendisini gören bazı kadınların pencereden baktığını da ifade etmiştir.

Urfa hamamlarında kadınların kına ve düğünlerde kına hamamı ve düğün hamamı yaptıklarını tahmin etmekteyiz (Akbıyık, 2015: 28). Kadın eğlencelerinin en önemlisi düğünlerdir. Eskiden kadın düğünleri avlusu (hayat) geniş evlerinde yapılırdı. Kadınlar düğünü Cumartesi günü yapılır, sabahtan öğlene kadar sürerdi. Öğleden sonra da aynı yerde erkek düğünü yapılırdı. Kadın düğünlerinde genellikle keman, cümbüş ve darbukadan oluşan ince saz çalınırdı. Bazen de davul zurna çalınırdı. Keman, cümbüş çalanlar genellikle gözleri görmeyen (âmâ) kişiler olurdu (Akbıyık, 2015: 30). Kadınların sokaktan izole edilmiş hayatlı evlerin avlusunda düğün eğlencelerinde bulunmaları ve âmâ çalgıııların da orada olması birer mahremiyet nişanesi olarak kabul edilebilir.

\section{Müslüman Urfa Kadının Sözcüklerdeki ve Mahkemedeki Mahremiyeti}

Urfa toplumsal hayatına kadının mahrem yaşamında kullandığı mekânlar üzerinden bakmaya çalıştığımızda sokak, ev, hamam, düğün eğlencelerinin dışında bir de kadının mahkemeyle olan ilişkisini de değerlendirmek gerekebilir. Sicillerden hareketle bazı kadınların mahkemeye doğrudan başvuru yaptığını bazılarının ise mahkeme kâtibini eve davet ederek vekâlet verdiklerini görmekteyiz. Bu kadınlar için namuslu, iffetli ${ }^{10}$ anlamlarını taşıyan muhadderat-ı nisa tabiri kullanılmıştır. ${ }^{11}$ Tucker, bu kavramı 18. yüzyıl hukuk düşüncesinde tecrit edilmiş kadın kategorisinde ele almaktadır. Gerekli işler için bile evden çıkmayan bu kadınlara muhadderat denmiştir. Fakihler bu kadınların mahkemedeki işlerini duruma uyarlamak için bir yol bulmuştur: kadınların ifadelerini mahkeme önünde dile getirecek iki kişi, tam yasal ehliyetle onlar adına ifade verebilmiştir. Özel bir kategori olarak muhadderat kadınlar, tanınmış ve saygı görmüş olsa da tüm kadınların böyle bir yaşam benimsemesi önerilmiş değildir. Bilakis fıkıh kaynakları, onaylanmış ve normal bir eylem olarak kadınların mahkemede bizzat ifade verdiği örneklerle doludur. Tecrit edilmiş yaşam biçimi kadınlar için bir seçenektir ama şart olmadığı gibi çoğundan böyle bir hayatı seçmesi de beklenmemiştir (Tucker, 2015: 262). Peirce, bu tür kadınların mahkeme alanına gelmediğini ve mahkemenin talep doğrultusunda görevlendirilen bir memur vasıtasıyla onların ayağına gittiğini ifade etmektedir (Peirce, 2005: 206). Genellikle kocaları zengin olan ya da toplumda statü olarak üst bir pozisyonda bulunan ailelerin hanımları mahkemeye işlerini hallettirmek istediklerinde bu yöntemi kullanıyordu (BOA, MŞH. UŞS: 205/132-58). Bu yöntem bir yönüyle de mahkeme alanının büyümesi

\footnotetext{
${ }^{10}$ Kubbealtı Lugatı: "Muhadderat", erişim: 08.10.2018. http://lugatim.com/s/MUHADDERAT

${ }^{11}$ BOA, MŞH. UŞS: 206/331-123. BOA, MŞH. UŞS: 208/880-181. BOA, MŞH. UŞS: 214/79-40. BOA, MŞH. UŞS: 220/627-8, 220/648-18, 220/1135-346, 220/1154-362, 220/1189-395, 220/1194-399. BOA, MŞH. UŞS: 222/415-248, 222/429-256, 222/496-288, 222/530-311, 222/550-323.
} 
anlamına geliyordu (Peirce, 2005: 208). Ebussuud Efendi'nin söz konusu hususta verdiği fetvalardan yararlanarak muhaddere teriminin sınırlarını belirlemeye çalışan Peirce, sözcüğün en yakın anlamıyla "saygıdeğer" manasına geldiğini ve namuslu davranışlarıyla tanınmışlık yanında, örtünme, eve kapanma uygulamasını da içerdiğini belirtmiştir (Peirce, 2005: 209). Sadece Müslüman kadınlara özel bir tanım olmadığını ve bu özellikleri taşıyan gayrimüslim kadınların da bu başık altında nitelenebileceğini ifade eden Ebusuud'un ifadesi Peirce'ye çok samimi gelmemiş olacak ki fetva makamından çıkan bir düzenleme olduğu için şeriatın burada ağır bastığını dile getirmiştir. Müftünün verdiği fetvalarda eğer bir kadın köy halkıyla olan ilişkisini kendisi görür ve çeşmeden su getirirse bu kadın muhaddere sayılmayacaktır. Diğer bir fetvada ise bir kadın hamama ya da kıra veya köylere gezmeye giderse yanında da hizmetçileri veya onu koruyacak birileri olursa, kadın da onurunu ve ağırbaşlılığını muhafaza ederse bu kadın muhaddere sınıfından sayılacaktır (Peirce, 2005: 209). Bu bakımdan yaptığı iş gereği halk içine çıkan kadın - dışarıdaki işini görecek, hatta kuyudan suyunu çekecek hizmetçisi bile bulunmayan kadın - saygınlığını ve onurunu korumada varlıklı kadına göre daha zor durumdaydı. Daha açıkçası suçlu olsun olmasın, toplum kuşkusuna ve suçlamasına daha kolay hedef oluyordu. Böyle olunca, daha varlıklı, daha yüksek sınıftan kadınların yalnızca sokağa çıkmama nedeniyle kendiliğinden elde ettikleri saygınlık, bu kadınlardan esirgeniyordu (Peirce, 2005: 210). Urfa'da da gördüğümüz bu uygulamada muhadderattan sayılan kadınların varlığının bilinmesi ve mahkemenin alanını eve doğru genişletmesi şüphesiz bu kadınların toplumsal statüsü ve mahrem yaşamlarından kaynaklanmaktadır. Özellikle Urfalı kentli kadınların toplumsal sınırlarından bahsederken bu kavramın kullanım alanını da hesaba katma gereği doğmuştur. Bu bakımdan kadın bedeninin bir kez daha hukuksal, siyasal, toplumsal ve ahlaki sınırları belirlemedeki etkisi önemli bir işaretçi olmuştur (Peirce, 2005: 210).

Vekil kullanan kadınların sayısının fazla olması diğer illerde de göze çarpmaktadır. Jenings'in tespitlerine göre, Müslüman kadınların vekil atama oranı gayrimüslimlere göre daha yüksektir. Zimmilerin yalnızca \%25'i vekil atarken Müslüman kadınların \%36'sı mahkemede vekil ile temsil edilmiştir. Bu oranlar Kayseri söz konusu olduğunda \%23'e kadar düşebilmekte, \%33'ü de geçmemektedir. Ortalamayı diğer şehirler yükseltmektedir. Mesela Amasya'da kadınların \%37'si, Karaman ve Trabzon'da \%53'ü vekil kullanmıştır (Bilgin, 2013: 318). Urfa'da ise Müslüman kadınların \%53'ü vekil kullanmıştır. ${ }^{12}$ Müslüman erkeklere olduğu gibi gayrimüslim dava vekillerine de Müslüman kadınların vekâlet verdiklerine şahit olmaktayız (BOA, MŞH. UŞS: 219/18-19, 219/39-39, 219/397-254, 219/402-258). İstedikleri zaman bu vekilleri azletme ve yerine yenisini atama hususunda da kadınların yetkilerini kullandığını öğrenmekteyiz. Bir dava örneğinde Fatma'nın Bedros'a verdiği vekâlet yetkisini elinden alıp İbrahim

\footnotetext{
${ }_{12}$ Urfa sicillerinden 1845-1848 yılları referans alınarak tespit edilmiştir. Bkz. Serkan Şenel, Geç Dönem Osmanlı Urfa'sında Kadın, Kadının Sosyo-Ekonomik Statüsü ve Mahremiyeti (1845-1915), (Yüksek Lisans Tezi, Harran Üniversitesi Sosyal Bilimler Enstitüsü, 2018).
} 
Halil'e vermesine Bedros'un hıyanet içerisinde olması sebep gösterilmiştir (BOA, MŞH. UŞS: 219/418-260, BOA, MŞH. UŞS: 220/895-178). Kadın vekâlet vereceği zaman genelde birilerinin kadını tarifleriyle marifetü'z zat olan falan Hanım şeklinde bir tanımlama ihtiyacı olduğunu görüyoruz ve kadını tanıyan bu birileri de genellikle erkek oluyor. Buradan hareketle bu dönem kadını yine çoğunlukla işini görmekte erkeklere muhtaç ya da onlara ihtiyacı vardı denilebilir. Bu çerçeve kadının doğrudan faal olabildiği ya da olamadığı alanları göstermesi bakımından fikir verebilecek niteliktedir.

Mekânlar kadar önemli olan bir diğer mahremiyet göstergesi de hiç şüphesiz kadını hem mahkemede hem de toplumsal hayatta ifade ederken ona yönelik olarak kullanılmış ifade biçimleridir. Genellikle hem Urfa şer'iyye sicillerinde hem de diğer illerin mahkeme kayıtlarında kadını tanımlarken kullanılan ifadelere baktığımızda kadınların veya erkeklerin yaşını belirtmekten ziyade hangi yaş aralığında iseler ona göre bir adlandırma veya kategori yapıldığını görmekteyiz. Arapçada kelimelerin dişil ve eril yönleri bulunduğundan şahıslara yönelik ifadelere bu durum yansımıştır. Örneğin, küçük kız çocukları sagire, fiziksel olgunluğa erişen kız çocukları ise kebire ya da bâliğa $a^{13}$ olarak anılırdı. Eğer kız çocuğu fiziksel olduğu kadar toplumsal ve yasal olgunluğa da erişmişse baliğa ve âkila diye belirtilirdi (Peirce, 2014: 171). Aslında çocukluktan evliliğe kadar genel olarak yaşam dilimini kız sözcüğü özetlemektedir. Bu terim birinin kız çocuğu anlamında kullanılabildiği gibi bekâreti vurgulamak anlamında da kullanılabilir. Peirce, bakire sözcüğünün evlenmemiș ve ergenlik çağını geçmiş dişiyi anlatırken biraz yanıltıcı olabileceğini dile getirmektedir (Peirce, 2014: 173). Kız evlenip kadın olduktan sonra toplumda çeşitli adlandırmalarla anılır. Gelin, Avrat, Hanım ve Hatun gibi isimlendirmeler örnek olarak gösterilebilir. Hanım genellikle başından evlilik geçen kadınları nitelerken Hatun kavramı daha çok soylu ailelerden gelen kadınlar için kullanılmaktadır.

Şer'iyye sicillerinde geçen ve mahremiyet nişanesi olarak kabul edebileceğimiz sözcük kullanımlarına değinmek gerekirse kadınlar belgelerde kendilerinden doğan çocuklarını ifade ederken firaş kelimesini tercih etmiştir. ìlgili sözcüğün anlamına baktığımızda "yatak, döşek" manasını taşımaktadır. ${ }^{14}$ Kadının firaş kelimesini kullanması Hz. Peygamberin “çocuk kimin döşeğinde doğarsa ona aittir" hadisine (Buhârî, 3, 100). de işaret etmek için kullanılmış olabilir. Bu bakımdan doğumun meşru olduğunu ve doğan çocuğun nesebinin sabit olduğunu ifade etmek için ilgili terim kullanılmıştır denilebilir. Evli olan kadınlar bir erkeğin nikâhı altında bulunduklarını ifade etmek için menkûha sözcüğünü kullanmıştır. Dahası zifaf gerçekleşmiş ise medhûlün-bihâ ${ }^{15}$ terimi $^{2}$

\footnotetext{
${ }^{13}$ Bir kızın baliğa sayılabilmesi onun hayz görmesi ile alakalı bir durumdur. Mahkeme şüphe duyduğu durumlarda bu durumu bizzat tespit ettirmiştir. Bkz. BOA, MŞH. UŞS: 222/426-254, 222/501-293.

${ }^{14}$ Bir kadının ancak kendisinin sahibi olan bir şahıs için doğurabilir olması, sâhib de ya kocasıdır ya da cariyeye nispetle efendisidir. Erdoğan, Fıkıh ve Hukuk Terimleri Sözlüğü, 146.

15 Kendisiyle gerdeğe girilmiş kadın, zevce. Kubbealtı Lugatı: “medhûlün-bihâ", erişim: 12.10.2018. http://lugatim.com/s/medh\%C3\%BB|
} 
tercih edilmiştir ki bu terimin anlamına indiğimizde kadının artık bâkire olmadığı manası anlaşılmalıdır. Nikâh akitlerini incelediğimizde kadınların aldıkları ya da alacakları mehir miktarın belirttikten sonra nefsimi falancaya teslim ettim veya nefsimi falana tezvic ettim demeleri de bir tür mahremiyet nişanesi olarak kabul edilebilir. Bu tür bir ibare ile bana her şeyimle sahip olabilir gibi bir anlam ortaya çıkmaktadır. Belge üzerinde bunun açıkça belirtilmiş olması mahremiyet açısından önem arz etmekle birlikte kadının mehrini alarak nefsini satması gibi bir anlama da kapı aralamaktadır. Mehir karşılığında kadın kocanın kendi buz'una (yani cinsi yönden yararlanma) izin vermektedir (Akyüz: 2005: 214). Kadının buna razı geldiğini ifade eden mahrem ifadesi kadı sicillerinde "nefsimi şu kadar mehir karşılığında falancaya teslim ettim” şeklinde geçmektedir. Eşlerin anlaşmazlıklarını ifade ederken kullandığı terimlerden birisi de geçimsizlik anlamına gelen adem-i imtizacın yokluğu iken bir diğeri de hukuk-ı zevciyet'e uymamak olarak adlandırdıkları ifade kapsamında eşlerin birbirine karşı hak ve ödevlerinin olduğunu görmekteyiz. Mahremiyet yönü ile bu terimi ele aldığımızda cinsel ihtiyaçları olan kadın ve erkeğin meşru bir zemin olan evlilikte bu ihtiyaçlarının taraflardan biri cihetiyle giderilmediğinde mesele mahkemeye şikâyet konusu olmaktadır. Dolayısıyla burada mahkemenin konumu itibariyle eşler arası mahrem bir soruna hem şahit olması hem de çözüm araması söz konusu iken eşlerin de mahrem bir meseleyi mahkemenin gündemine taşıyacak cesaretleri bu sözcüğün anlamının altında gizlidir. Çiftler boşandığında kadının hayatının ilgili devresindeki pozisyonunu ifade etmek için mutallaka ${ }^{16}$ veya metrûke ${ }^{17}$ kelimeleri kullanılmıştır. Kadınların hem yaşamlarındaki mahrem kesitleri belirtmesi açısından hem de kadının hayatının hangi evresinde olduğunu bildiren göstergeler olması bakımından bu tür kavramların Osmanlı toplumsal hayatında birer kimlik işaretleyicisi olarak yadsınamaz öneme sahip olduğunu anlamaktayı.

Urfa şer’iyye sicillerinde geçen dava örnekleri üzerinden Urfa kadınına bakan yönüyle mahrem ifade ve sözcüklerin kullanımını biraz irdelemek gerekirse bu bahse Kavâf Mustafa'nın davasıyla başlamanın yerinde bir tercih olacağı kanaatindeyiz. Gülikli mescid-i şerifi mahallesi sakinlerinden Kavâf Hacı Mustafa bin Hacı İbrahim kızı Ayn Zeliha üç buçuk yaşında iken evin penceresindeki cağa çıkarken bikri zail olmuştur. Babası Hacı Mustafa mahkemeye başvurarak toplum nazarında hatırı sayılır şahitlerle birlikte bu talihsizliği kayıt altına aldırmıştır. Şahitlerin arasında Müftizâde Mustafa Efendi, Karındaşı Mahmut Efendi, Mustafa Hafız Efendi, Harran Şeyhizade Şeyh Hasan gibi önemli kişiler vardır (Yıldız, 2010: 180). Ayn Zeliha'nın babasının bu meseleye ihtimam gösterip şahitleri organize edip bu mahrem meseleyi mahkemede kayıt ettirmesinin sebebi ilerleyen zamanda kızı evleneceği zaman başına gelebilecek sıkıntıyı şimdiden bertaraf ettirip eline kızım ahlaken sağlam belgesini almaktır. Babanın bu belgeyi alması

\footnotetext{
${ }^{16}$ Şemseddin Sami, Kâmus-ı Türkî, “Mutallaka”: Tatlik olunmuş zevce, bırakılan karı. (i̇stanbul: Çağrı yayınları, 2010), 1364.

${ }^{17}$ Kocası tarafından terkedilmiş veya kocasından boşanmış kadın, 12.10.2018 http://lugatim.com/s/METR\%C3\%9BKE
} 
ve mahrem bir hususu mahkemeye saygın şahitler huzurunda taşıması namus kavramına verilen önemi gözler önüne sermektedir. Ayrıca şahitlerin bu meselede sorumluluk alarak kendilerini meselenin şahidi olarak göstermeleri ve şahitlerin isimlerinin başlarına gelen sıfattan da anlaşılacağı üzere toplum nezdinde kıymeti olan sözü geçen bu insanların söz konusu hususa önem verdiklerini göstermektedir. Ayrıca Ayn Zeliha'nın babası ve dedesi de hacı olmaları hasebiyle toplumda statü sahibi olan bir ailenin meseleye verdiği önem kayda değer nitelikte gözükmektedir.

Mahremiyetin Urfa toplumundaki sınırlarını yansıtması bakımından paylaşacağımı bir diğer dava örneğinde ise Osman'ın Meryem'i mahkemeye şikâyet ederken aşikâr hale gelen aralarındaki mahrem hususa tanıklık etmekteyiz (BOA, MŞH. UŞS: 208/512-24). Osman'ın mahkemeye kaydettirdiği ifadesinde "mehr-i muaccelini vermeme rağmen nefsini bana teslimden imtina" itaat ve inkıyâd etmemekle" gibi bir ifadesi söz konusudur. Burada geçen imtina' kelimesi "kaçınma, çekinme ve geri durma" anlamına gelmektedir (Develioğlu, 2011: 499). Mahkemenin ise Meryem'e tembihte bulunarak “Osman'a itaat ve inkıyâd ve hukuk-ı zevciyete riâyete mezbure Meryem'e tenbih olunduğu tescil" ifadesindeki inkıyâd "boyun eğme, kendini teslim etme" manasına gelmektedir (Develioğlu, 2011: 506). Konuya kadın ve mahremiyet cihetiyle bakarsak, Meryem henüz böyle bir şeye kendisini hazır hissetmemiş olabilir. Erkeğin mevzuyu mahkemeye taşıması ve mehrini vermesiyle bu meselenin hallolmasını beklemesi kadının psikolojisini hiçe saymak manasına gelebilir. Ayrıca mahkemenin de tembih merci olması ilginçtir. Mahkeme hukuken kadını bu duruma mecbur bırakırken kadının sosyo-psikolojik vaziyetini burada göz ardı etmiştir. Böyle bir mevzunun varlı̆̆ı toplum nazarında da aşikâr hale gelmiştir. Öbür yandan kadın psikolojik açıdan belki de hazır olmadığı bir hususta ki bu durumu i̇slam dini de onaylamamaktadır- hukuken zorlanmıştır. Bu bakımdan meselenin arka planını da tahmin ederek yaklaştığımızda bahsettiğimiz hususlar belgede görünmemesine rağmen olmadığı anlamını taşımaz çünkü belgede kadın bu konuda ne hissetmiş, de kocasına nefsini teslim edememiş bunu bilemiyoruz, kadının bu konudaki düşüncelerine ulaşabilmemiz için mahkemenin kadının sesine de kulak vermesi meselenin anlaşılmasında önemli bir nokta olabilirdi. Erkeğin cihetinden bakılınca kendi karısını bir mahkeme kadısı huzurunda sorgulama ve şikâyet söz konusudur. Diğer bir ifadeyle mahrem bir meselenin hukuk adamına ve hukuk tarafına çekilmesi söz konusudur. Aile içi iletişimin eksik olmasından kaynaklı bir durumdan dolayı Osman, anlaşmazlığı hukuki boyuta taşımış ve şer'i mahkemenin kendisine sunduğu hakları kullanmıştır. Daha önce eşler kendi aralarında konuşabilmişler mi biz bunu da bilemiyoruz. Kocanın söylediği tek husus mehrini verdim, nefsini bana teslim etsin şeklinde diretmesidir. Mahremiyetin sınırları bakımından altının çizilmesi gereken bir dava örneği olduğunu düşündüğümüz bu belgede dikkat çeken husus kadının mehr-i muaccelini aldıktan sonra zifaf için hem kocası hem de mahkeme yoluyla 
zorlanmasıdır. Urfa şer'iyye sicillerinde bu davalara benzer kayıtlara ziyadesiyle rastlanılabilir.

Bazı kadınların çok eşlilikten kaynaklı sıkıntıları olmuştur. Genellikle bu sıkıntıların baş göstermesinde mekân kısıtlılığının etkili olduğunu müşahede etmekteyiz. Öyle ki Tanyeli'nin ifade ettiği üzere mekân ne kadar lüks ise mahremiyeti yaşayacak alanın tanıdığı imkân da o denli geniştir. Ancak mekân ve mahremiyet bahsinde geçtiği üzere bazen mekânın kısıtlı olduğu hallerde mahremin korunması ve yaşanmasında aksaklıklar olabiliyordu. Rabia kocası Mehmed'le bir odalı olan bir yerde kaldıklarını ve kocasının diğer bir eşi de olduğundan tek odada kalmayı istemediğini ve Mehmed'in kendisi için başka bir oda açmasının gerekli olduğunu ifade etmektedir. Mehmed de bunu kabul eder ve aynı zamanda kendisinden ilgi ve alaka isteyen Rabia'ya gerekli alakayı göstereceğini ve ona başka bir oda açacağını taahhüt eder (BOA, MŞH. UŞS: 208/999-233). Bu belgede Rabia'nın cesaretini, arzusunu ve ihtiyaçlarını okuyabiliyoruz. Rabia belli ki cesur bir kadın çünkü kocasından ayrılmak yerine çözüm için farklı bir oda istemektedir. Kadın, kocasından kendisiyle de alakadar olmasını beklemektedir. Üstelik bunu mahkemeye iletebilecek cesarette bir duruş sergilemektedir. Kadının mahrem olan bir hususu hukuksal statüsünü kullanarak mahkemeye taşımasına ve kocasını kadı huzuruna çağırttırarak kocasının hal ve gidişatına bir ayar verdirmesi söz konusudur. Rabia hakkı olanı mahkeme desteğiyle elde etmiştir. Avaş bint Halil'in kocası Musa'ya yönelik tutumunda da aynı şikâyetleri görebilmek mümkündür. Avaş, Musa'dan şikâyetle Musa'nın onu bir hanede nafakasız ve kisvesiz bıraktığını ve zevciyete itaat etmediğini ayrıca adamın başka bir karısı olduğunu ve Avaş’ı ihmal edip diğer karısıyla daha çok vakit geçirdiğini söyleyerek kocasını hukuk-ı zevciyete itaate davet etmiştir (BOA, MŞH. UŞS: 208/215-343). Kadının mahkemeye bu özel ve zaruri olan halini aks ettirmesi ve meseleyi hukuki zemine taşıması oldukça takdire şayan bir durumdur. Bu davalarda hukuksal haklarının bilincinde olan ve bunları kullanan bir Urfalı kentli kadın profiline şahitlik etmekteyiz.

Urfa evlerinin selamlık ve haremlik kısımlarının olduğuna dair anlattıklarımızda bu evlerin mahremiyetin yaşanması için hane halkına özel bir alan tanıdığına işaret etmiştik. Selamlık kısmında olması gereken Bekir'in yer yer kaçamak yaparak ihlal ettiği haremlik kısımlarına ilişkin Urfa kadı sicillerinde şöyle bir dava örneğine rastlamaktayız ${ }^{18}$ Belgeden anlaşıldığı üzere Osman Efendi'nin kızı olan Hatice Hanım üst tabakadan bir hanımdır. Belli ki bu kadın daha önceden de kocasının bu tür hareketlerini görmüş ve kocası şartlı talak yeminini ortaya

\footnotetext{
${ }^{18}$ Hatice bint Osman Efendi kocası Bekir bin Bozo muvacehesinde merkûm Bekir zevc-i dâhilim olup tarihinden sekiz mâh mukaddem ben kayınpederim Osman Efendi'nin selâmlık dâiresinden harem dâiresine meftûh kapıdan mümâ ileyh Osman Efendi'nin halîleleri harem dâiresinde bulundukları hâlde duhûl eder isem zevcem Hatice benden talâk-ı selâse ile mutallak olsun diye şart u tatlîk edip tarihinden yirmi gün mukaddem mümâ ileyh Osman Efendi'nin halîleleri hârem dâiresinde bulundukları halde merkûm Bekir harem dâiresine duhûl ve ol vechile şart-ı mezkûrun vuku'una binâen merkûm Bekir'den talâk-ı selâse ile mutallak olmamla zimmetinde mütekarrır ve ma'kûd-ı aleyh bin guruş mehr-i müeccelim ile iddetim inkızâsına değin nafakamı taleb ederim diye davâ ettikde... (BOA, MŞH. UŞS: 208/39-261).
} 
koymuştur. Ancak ne var ki Bekir sözünde durmayıp yine aynı hal ve hareketine devam edince karısı onu mahkemeye vermiş ve netice itibariyle de 1000 guruş mehr-i müeccel ve iddet nafakasını almaya hak kazanmıştır. Bekir durumu inkâr etse de toplum tarafından önde gelen şahıslar bu davaya şahitlik etmiştir. Netice itibariyle Hatice Hanım haklı görülmüştür. Bu mevzu, hane içi mahremiyetin sınırlarını net bir şekilde anlatması bakımından önemli kabul edilmelidir. Evin haremlik-selamlık bölümlerinin olduğunu ve haremliğe içeride Osman Ağa'nın haremleri varken girilemeyeceğini belge bize söylemektedir. Evdeki damat bunu sabote ettiğine göre damadın namus konusunda sıkıntılarının olduğunu anlamaktayız. Hatice Hanım'ın tahammül sınırlarının zorlandığını ve işin boşamaya kadar gittiğini görebiliyoruz. Diğer yandan asil bir ailenin kızı olan Hatice Hanım'ın da kadı mahkemesini kullanmakta tereddüt etmediğini ve ailesinin mahrem bir meselesinin mahkemeye taşındığını, durumun afişe edildiğini mahkemeye yansıyan yüzüyle ilgili belgeden haber alıyoruz. Bekir b. Bozo için herhangi bir Efendi, Bey ya da Hacı gibi toplum nazarında kıymeti olan sıfatlar kullanılmadığından kendisi için asil bir aileden gelmemektedir gibi bir çıkarım yapılabilir. Burada kefâet (küfv) konusu da öne çıkmaktadır ki görüldüğü üzere aynı toplumsal statüde olmayan bir kadınla erkeğin düştüğü durum bu davada yansıtılmaktadır. Kefâetde (küfv) erkeğin, kadının toplumsal statüsüne yakın olması önem arz etmektedir. Bu tür bir statüsü olmayan erkek, tıpkı Bekir b. Bozo'da olduğu gibi kadının toplumsal hayattaki konumuna uyum sağlayamayabilir.

Haremlik-Selamlık meselesi sadece fiziki ortamda kalmamış bu durum komşuluk ilişkilerine de yansımıştır. Yaşlı bir kadın olan Zemzem Hanım komşusu Halil'in avlusundaki kuyudan su almaktadır. Kendisi bir süre sonra vefat edince kızları Elif ve Emine su almaya devam eder ancak Halil bu durumu evde erkek çocuklarının bulunduğunu ve Zemzem kadının yaşlı olduğunu ancak kızlarının genç olmalarından dolayı mahrem olmaları gerekçesiyle engellemiştir (Taş, 2016: 3).

\section{Sonuç}

Netice itibariyle Urfa'da kadının mahrem yaşamının sokaktan başlayarak belirli dereceler halinde hanesinde de devam ettiğinin ayrımına varırken aynı zamanda mahremiyetin lükse göre de şekillendiğini ifade ettik. Öyle ki imkânların sağladığı ölçülerde gerçekleşen mahremiyetin uygulama alanının daha geniş olduğu sonucuna ulaştık. Öbür yandan dar mekânlarda da mahremiyetin yaşanabildiğini gösteren örnekler sunduk. Mahremiyeti sadece ev, sokak, mahalle gibi mekân ölçeğinde değil aynı zamanda mahkemede kullanılan ifadelerde ve kadına yönelik kullanılan sıfatlarda da aradık. Böylelikle mahkeme belgelerinde ve gündelik hayatta kadına yönelik kullanılan sözcüklerin kadının mahremiyetine yönelik içerdiği ipuçlarını analiz etme imkânı bulduk. Bu analiz sonucunda Müslüman Urfa kadınına işaret eden ve 1866-1895 yıl aralığını 
kapsayan döneme dair mahrem sınırların tespitini yaparak ön plana çıkartmaya çaba sarf ettik.

\section{Kaynakça}

\section{Birincil Kaynaklar}

\section{Urfa Şer'iyye Sicilleri}

BOA, MŞH. UŞS: 205/159-68.

BOA, MŞH. UŞS: 206/331-123.

BOA, MŞH. UŞS: 208/39-26, 208/58-269, 208/215-343, 208/512-24, 208/671-91, 208/673-80, 208/880-181, 208/999-233.

BOA, MŞH. UŞS: 210/16-205, 210/27-209, 210/561-178.

BOA, MŞH. UŞS: 214/79-40.

BOA, MŞH. UŞS: 219/18-19, 219/39-39, 219/397-254, 219/402-258, 219/418-260.

BOA, MŞH. UŞS: 220/669-34, 220/627-8, 220/648-18, 220/895-178, 220/1119-335, 220/1135-346, 220/1154-362, 220/1189-395, 220/1194-399.

BOA, MŞH. UŞS: 222/415-248, 222/426-254, 222/429-256, 222/496-288, 222/501-293, 222/530-311, 222/550-323.

Ahmed Cevdet Paşa. Mecelle-i Ahkâm-ı 'Adliye. İstanbul: Matbaa-i Osmaniye, 1300.

Buckingham, J. S. (1827). Travels in Mesopotamia (1786-1855). London.

Buhârî, Kitabu'l-Büyû', 3, 100.

\section{İkincil Kaynaklar}

Abuzer A. (2015). "Şanlıurfa'da Geleneksel Kadın Eğlenceleri ve Toplantılar", Şurkav, 22, 28-32.

Akkoyunlu, Z. (1988). Geleneksel Urfa Evlerinin Mimari Özellikleri Yüksek Lisans Tezi, Gazi Üniversitesi Fen Bilimleri Enstitüsü.

Akyüz, J. (2007). “Osmanlı Kadınlarının Hukuksal Haklarını Kullanımı Hakkında Bazı Değerlendirmeler”. Hacettepe Üniversitesi Türkiyat Araştırmaları Enstitüsü Dergisi, 6, 75-91.

Asoğlu, í. (2019). Birliktelikten Yol Ayrımına Urfa Kazasında Gayrimüslimler (18801910), Doktora Tezi, Harran Üniversitesi Sosyal Bilimler Enstitüsü.

Aydın, M. A. (2013). Osmanlı'dan Günümüze Cinsiyet, Mahremiyet ve Mekân Çalıştayı, İstanbul: TDV Yayınları.

Bayartan, M. (2005). "Tarihi Coğrafya Çalışmaları Açısından Şehir ve Osmanlı Şehri”, İstanbul Üniversitesi Coğrafya Dergisi., 13, 85-92.

Behar, C. (2004). Bir Mahallenin Doğumu ve Ölümü (1494-2008), İstanbul: Yapı Kredi Yayınları. 
Benzer, Z. (2015). 222 Numaralı Urfa Şer'iyye Sicilinin (Birinci Kısım) Transkripsiyon ve Değerlendirmesi. Yüksek Lisans Tezi, Karadeniz Teknik Üniversitesi Sosyal Bilimler Enstitüsü.

Bilgin, A. (2018). “Mahremiyet ve Kazanç Arasında Osmanlı Kadını”. Tanzimat Öncesi Osmanlı Toplumunda Cinsiyet, Mahremiyet ve Sosyal Hayat. 1.bs. Ankara: TDV Yayınları.

Dengiz, E. B. (2001). Boundaries Of Gendered Space: Traditional Turkish House, Yüksek Lisans Tezi, Bilkent Üniversitesi Güzel Sanatlar Enstitüsü.

Develioğlu, F. (2011). Osmanlıca-Türkçe Ansiklopedik Lûgat, 28.b.s. Ankara: Aydın Kitabevi.

Doğan, i. (2002). “Korumacılığın Geleneksel Kent Kültüründen Çıkarması Gereken Dersler”, Ankara Üniversitesi Eğitim Bilimleri Fakültesi Dergisi, 35, 15-23.

Ekinci, A. (2018) “Osmanlı Urfası'nın “Amentüsü” Olan Mekânlar”, Osmanlı Urfası II. 1.bs. İstanbul: Orient Basım.

Erdoğan, M. (2017). Fıkıh ve Hukuk Terimleri Sözlüğü, 4.bs. İstanbul: Ensar Neşriyat.

Ergenç, Ö. (1984). Osmanlı Şehrindeki Mahallenin İşlev ve Nitelikleri Üzerine, İstanbul: Osmanlı Araştırmaları IV.

Ergenç, Ö. (2013). Osmanlı'dan Günümüze Cinsiyet, Mahremiyet ve Mekân Çalıştayı, İstanbul: TDV Yayınları.

Gülbiçin, Y. (2006). Günümüze Gelen Şanlıurfa Hamamları, Yüksek Lisans Tezi, Van Yüzüncü Yıl Üniversitesi Sosyal Bilimler Enstitüsü.

Kalender, S. (2013). “Uğur Tanyeli - Engin Gerçek, İstanbul'da Mekân Mahremiyetinin ihlali ve Teşhiri: Gerilimli Bir Tarihçe ve 41 Fotoğraf”, FSM İlmî Araştırmalar Dergisi, 2, 397-402.

Kürkçüoğlu, M. F. (2018). Çapıt Top, İstanbul: Kastaş Yayınevi.

Kürkçüoğlu, S. S. (2014), "Şanlıurfa'da Geleneksel Toplanma ve Buluşma Adetleri”, Şurkav, 20, 40.

Orhun, D. (2010). “The Relationship Between Space And Gender In Traditional Homes Across Turkey", Journal of Architectural and Planning Research. 7/4. Winter, 340-355.

Öğüt, S. (2003). Mahrem, DiA, 27, 388-389.

Peirce, L. P. (2014) “Ekberiyet, Cinsellik ve Toplum Düzeni: Modern Dönemin Başlangıcında Toplumsal Cinsiyetle ilgili Osmanlı Söz Dağarcığı”, Modernleşmenin eşiğinde Osmanlı Kadınları. 161-188, Ed. Madeline C. Zilfi, 4.b.s. İstanbul: Tarih Vakfı Yurt Yayınları.

Peirce, L. P. (2005). Ahlak Oyunları, 1.bs. İstanbul: Tarih Vakfı Yurt Yayınları.

O’ Meara, S. (2014). Mekân ve Müslüman Şehir Hayatı Fes Labirentinin Sınırlarında, İstanbul: Açılım Kitap.

Sami, Ş. (2010). Kâmûs-ı Türkî, İstanbul: Çağrı yayınları.

Şenel, S. (2018). Geç Dönem Osmanlı Urfa'sında kadın, kadının sosyo-ekonomik statüsü ve mahremiyeti (1845-1915), Yüksek Lisans Tezi, Harran Üniversitesi Sosyal Bilimler Enstitüsü. 
Tanyeli, U., Gerçek E. (2012). İstanbul'da Mekân Mahremiyetinin İhlali ve Teşhiri: Gerilimli Bir Tarihçe ve 41 Fotoğraf, 1.bs. İstanbul: Metis Yayıncılık.

Taş, Y. (2016). “Mahkeme Kayıtları Işığında Osmanlı'da Komşuluk Hukuku: 19.yüzyılda Urfa Örneği”. Şurkav, 25, 3-9.

Tucker, J. E. (2015). İslam Hukukunda Kadın, Aile ve Toplumsal Cinsiyet, 1.bs. İstanbul: Açılım Kitap.

Tunç Yaşar, F. (2013). Osmanlı'dan Günümüze Cinsiyet, Mahremiyet ve Mekân Çalıştayı. İstanbul: TDV Yayınları.

Uğur, Y. (2015). "Şehirler ve Şehirleşme”, Osmanlı İmparatorluğu'nda Çevre ve Şehir, Ed. Mehmet Genç-Fehmi Yılmaz, 1.bs. İstanbul: Bayem Ajans, 293-327.

Üner, M. E. (2015). "Şeriyye Sicillerine Göre Urfa'da Kadın ve Aile (XVII-XVII. yüzyıllar)", Harran Üniversitesi İlahiyat Fakültesi Dergisi, 34, 22-48.

Yıldız, A. (2010). 204 Numaralı Şer'iyye Sicili Defterine Göre Urfa'da Ekonomik Sosyal ve Kültürel Hayat. Yüksek Lisans Tezi, Marmara Üniversitesi Sosyal Bilimler Enstitüsü.

Yılmaz, F. (1999/2000). XVI. Yüzyıl Osmanlı Toplumunda Mahremiyetin Sınırlarına Dair, Toplum ve Bilim, 83, Kış.

Internet Kaynakları

"Aynur Can, "Güzel Şehrin Esaslarını Anlamak", Bir Şehir Kurmak ve Yeni Bir Gündem Inşa Etmek”, $\quad$ erişim: 10.10 .2018$. https://www.youtube.com/watch?v=4VTetDl2Guw

Abuzer Akbıyık. "Urfa Hamamları: Vezir Hamamı",

http://www.abuzerakbiyik.com.tr/page_detail.php?page_id=24. Erişim:

06.11.2018.

“Fotosammlung Max von Oppenheim - Seriennummer: 9005, 10/6, 85d". Erişim: 9 Ekim 2018. https://arachne.uni-koeln.de/drupal/?q=node/2

Kubbealtı Lugatı: “Medhûlün-bihâ", erişim: 12.10.2018. http://lugatim.com/s/medh\%C3\%BBI

Kubbealtı Lugatı: “Muhadderat", erişim: $\quad$ 08.10.2018. http://lugatim.com/s/MUHADDERAT

Oppenheim, 10/6, 88c", https://arachne.uni-koeln.de/drupal/?q=node/2 